\title{
Patterns and controls of nitrogen stable isotopes of particulate organic matter in subtropical lakes
}

\author{
Binhe $\mathrm{Gu}^{1,2 *}$ and Claire L. Schelske ${ }^{3}$ \\ ${ }^{1}$ Fishery College, Guangdong Ocean University, 40 East Jiefang Road, Zhanjiang, Guangdong, 52488, China \\ ${ }^{2}$ Southwest Research and Education Center, University of Florida, 2685 SR 29 N, Immokalee, FL 34142, USA \\ ${ }^{3}$ Department of Geological Sciences and Land Use and Environmental Change Institute, University of Florida, Gainesville, \\ FL 32611, USA
}

Received 25 September 2009; Accepted 29 December 2009

\begin{abstract}
Nitrogen stable isotope composition $\left(\delta^{15} \mathrm{~N}\right)$ of particulate organic matter (POM) has been used to infer dominant nitrogen cycling processes in lakes. However, very few studies have compared the isotope variations in lakes along trophic state and other biogeochemical gradients. Here we report an analysis of $\delta^{15} \mathrm{~N}_{\mathrm{POM}}$ and selected environmental variables from 96 subtropical lakes to assess the patterns and controls

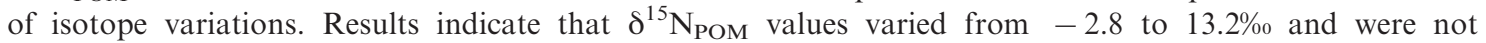
significantly correlated with total phosphorus (TP), total nitrogen (TN) and chlorophyll a (Chl a). The ${ }^{15} \mathrm{~N}$ depletion in POM was found across the entire trophic gradient and likely reflected contributions from planktonic nitrogen fixation. The ${ }^{15} \mathrm{~N}$ enrichment was attributed to high primary production and the contributions of anthropogenic wastes in eutrophic lakes, and the presence of microzooplankton in the water samples of the oligotrophic lakes. The $\delta^{15} \mathrm{~N}_{\text {POM }}$ was negatively correlated with water color and positively correlated with $\mathrm{pH}$. Because water color is indicative of light availability which affects phytoplankton growth and $\mathrm{pH}$ is significantly correlated with $\mathrm{Chl}$ a concentration in the study lakes, the close relationship between water color, $\mathrm{pH}$ and $\delta^{15} \mathrm{~N}_{\mathrm{POM}}$ therefore suggests primary productivity-driven isotope fractionation. Results from this study did not reveal the importance of trophic state, nitrogen concentration and surface area to the variations of $\delta^{15} \mathrm{~N}_{\mathrm{POM}}$ and points to the complex interactions of nitrogen cycling processes in lakes with diverse biogeochemical features.
\end{abstract}

Key words: Nitrogen fixation / nitrogen stable isotopes / particulate organic matter / subtropical lakes / trophic state / water color

\section{Introduction}

The stable nitrogen isotope ratio $\left(\delta^{15} \mathrm{~N}\right)$ of particulate organic matter (POM) has been used as an indicator for the source, availability and the cycling processes of nitrogen in lakes ( $\mathrm{Gu}$ et al., 1996; Teranes and Bernasconi, 2000; Lehmann et al., 2004; Gu et al., 2006). Previous studies have revealed that $\delta^{15} \mathrm{~N}_{\mathrm{POM}}$ varies over time in individual lakes (Gu et al., 1994, 2006; Lehmann et al., 2004; Syväranta et al., 2008; Hadas et al., 2009). Several studies have compared $\delta^{15} \mathrm{~N}_{\mathrm{POM}}$ among lakes. Gu et al. (1996) found a non-linear relationship between total phosphorus (TP) concentration and planktonic $\delta^{15} \mathrm{~N}$ in ten subtropical lakes with different trophic states. Patoine et al. (2006) reported a close relationship between abundance of nitrogen-fixing cyanobacteria and $\delta^{15} \mathrm{~N}_{\mathrm{POM}}$ in six

\footnotetext{
*Corresponding author: gubinhe@gmail.com
}

lakes of the northern Great Plains. In a recent review of literature data, $\mathrm{Gu}$ (2009) found higher $\delta^{15} \mathrm{~N}_{\mathrm{POM}}$ in eutrophic lakes than oligotrophic lakes around the world. A number of environmental variables such as primary productivity, stable isotope composition and concentration of dissolved inorganic nitrogen (DIN) and major nitrogen processes (nitrogen fixation, nitrification and denitrification) may influence the seasonal and inter-lake variations in $\delta^{15} \mathrm{~N}_{\text {POM }}$.

Primary productivity or phytoplankton growth rate may regulate the planktonic isotope composition in lakes. During nitrogen uptake, phytoplankton preferentially use the light isotope $\left({ }^{14} \mathrm{~N}\right)$, leading to isotope depletion in organic matter. Isotope fractionation decreases as the growth rate of phytoplankton increases and as the substrate level decreases (Montoya and McCarthy, 1995; Waser et al., 1998). Therefore, during the productive period of a seasonal cycle in eutrophic lakes, POM in 
Table 1. Descriptive statistics of nitrogen stable isotope ratios of POM and selected environmental variables in 96 Florida lakes. Data for surface area (Area) are available for only 44 lakes.

\begin{tabular}{|c|c|c|c|c|c|c|c|c|c|c|}
\hline & Area & $\mathrm{pH}$ & Alkalinity & Conductivity & $\mathrm{TP}$ & $\mathrm{TN}$ & TN:TP & Chl a & Color & $\delta^{15} \mathrm{~N}_{\mathrm{POM}}$ \\
\hline Statistics & $\mathrm{km}^{2}$ & SU & $\begin{array}{l}\mathrm{CaCO}_{3} \\
\text { mg. } \mathrm{L}^{-1}\end{array}$ & $\mu \mathrm{s} . \mathrm{cm}^{-1}$ & $\mu \mathrm{g} . \mathrm{L}^{-1}$ & mg. $\mathrm{L}^{-1}$ & $\begin{array}{l}\text { Molar } \\
\text { ratio }\end{array}$ & $\mu \mathrm{g} . \mathrm{L}^{-1}$ & PCU & $\%$ \\
\hline Mean & 50 & 6.73 & 25 & 140 & 37 & 1.03 & 192 & 13.3 & 71 & 3.2 \\
\hline Median & 1.13 & 6.77 & 12 & 121 & 18 & 0.88 & 117 & 5.5 & 39 & 2.6 \\
\hline Standard deviation & 285 & 1.06 & 31 & 98 & 53 & 0.71 & 1050 & 17.4 & 83 & 2.9 \\
\hline Sample variance & 80976 & 1.12 & 992 & 9511 & 2856 & 0.50 & 1101837 & 302.9 & 6881 & 8.4 \\
\hline Kurtosis & 44 & -0.38 & 3 & 4 & 13 & 19.04 & 46 & 4.1 & 9 & 2.3 \\
\hline Skewness & 7 & -0.23 & 2 & 1 & 3 & 3.77 & 7 & 2.1 & 3 & 1.2 \\
\hline Range & 1890 & 4.80 & 149 & 595 & 346 & 4.94 & 8313 & 76.2 & 499 & 16.0 \\
\hline Minimum & 0.04 & 4.27 & 0 & 0 & 3 & 0.28 & 5 & 0.8 & 0.01 & -2.8 \\
\hline Maximum & 1891 & 9.07 & 149 & 595 & 346 & 5.23 & 5327 & 77 & 499 & 13.2 \\
\hline
\end{tabular}

the surface waters is often enriched seasonally with ${ }^{15} \mathrm{~N}$ to a greater extent than that during an unproductive period or to that in oligotrophic lakes. Environmental variables such as water temperature, light regime and water color which influence phytoplankton growth often display a close relationship with $\delta^{15} \mathrm{~N}_{\text {POM }}(\mathrm{Gu}, 2009)$.

Nitrogen transformation processes also play important roles in regulating $\delta^{15} \mathrm{~N}_{\text {РOM}}$. For example, during nitrification, nitrifying bacteria convert isotopically light ammonium to nitrite and nitrate in oxygenated waters while denitrification reduces isotopically light nitrate to various forms of nitrogen gas. These processes often involve large isotope fractionation (Owens, 1987). The use of the remaining substrates or the resulting products may dramatically affect phytoplankton isotope composition (Syväranta et al., 2008; Hadas et al., 2009).

Unlike the uptake of dissolved combined nitrogen such as ammonium and nitrate, nitrogen fixation does not result in large isotope fractionation (Hoering and Ford, 1960; Delwiche and Steyn, 1970). Because atmospheric $\mathrm{N}_{2}$, the source of nitrogen used for nitrogen fixation, is also the standard used to calculate $\delta^{15} \mathrm{~N}\left[\delta^{15} \mathrm{~N}(\%)=\right.$ $\left.\left({ }^{15} \mathrm{~N} /{ }^{14} \mathrm{~N}_{\text {sample }} /{ }^{15} \mathrm{~N} /{ }^{14} \mathrm{~N}_{\text {standard }}-1\right) \times 1000\right]$, by definition, nitrogen fixers possess $\delta^{15} \mathrm{~N}$ values close to zero, which is often depleted compared to those of phytoplankton that use DIN as nutrients. Previous studies have shown that low $\delta^{15} \mathrm{~N}_{\mathrm{POM}}$ is often associated with the occurrence of nitrogen-fixing cyanobacterial blooms in the surface waters of lakes (Estep and Vigg, 1985; Gu et al., 2006; Patoine et al., 2006).

This study addressed the variation in $\delta^{15} \mathrm{~N}_{\mathrm{POM}}$ from 96 Florida lakes with a wide range in surface area, water color and biogeochemical gradients. The main purposes of this study were to (1) examine the distribution patterns of $\delta^{15} \mathrm{~N}_{\text {POM }}$ and (2) test if $\delta^{15} \mathrm{~N}_{\text {POM }}$ can be used as a reliable proxy of lake trophic state.

\section{Materials and methods}

All study lakes are located in Florida, USA between the latitudes of $26^{\circ} 31^{\prime} \mathrm{N}$ and $30^{\circ} 15^{\prime} \mathrm{N}$. Water samples from 89 study lakes were collected once by Florida
LAKEWATCH personnel in 1994 and 1995. These samples were taken at $0.5 \mathrm{~m}$ below the water surface from three lake stations, but only one of these water samples was used to determine $\delta^{15} \mathrm{~N}_{\mathrm{POM}}$. Stable isotope and ancillary data for additional seven Florida lakes were obtained from the literature ( $\mathrm{Gu}$ et al., 1996, 2006; Hoyer et al., 1998; Havens et al., 2003). pH and conductivity were recorded using a Hydrolab in the field and other water quality variables were analyzed in the laboratory following standard protocols (APHA, 1998).

For stable isotope analysis, 500 to $1000 \mathrm{~mL}$ of lake water was filtered onto precombusted $\left(500^{\circ} \mathrm{C}\right)$ Whatman glass fiber filters (pore size $=1 \mu \mathrm{m}$ ) that were then dried at $60^{\circ} \mathrm{C}$ in an oven. Large debris and zooplankton were removed with a forceps. Organic matter was scraped off the filters and loaded into tin capsules and analyzed for ${ }^{15} \mathrm{~N} /{ }^{14} \mathrm{~N}$ ratio using a VG PRISM II series mass spectrometer. All isotope values are reported relative to atmospheric $\mathrm{N}_{2}$. Analytical error was typically within $0.2 \% 0$

Difference between two sample means and correlation between a dependent and an independent variable were examined using SPSS software (Version 10). MannWhitney test was used for two sample comparison and Spearman's Rho test was used for correlation analysis. Statistics were considered significant at $p<0.05$.

\section{Results}

Nitrogen stable isotopes of POM and the other variables in the study lakes display large variations (Table 1). Surface area data were available for 44 lakes and varied from well less than 1 to nearly $2000 \mathrm{~km}^{2}$. pH varied from 4.27 to 9.07 with an average of 6.73. Lake color varied from 0.01 to $499 \mathrm{PCU}$, representing lakes with clear or highly stained water. TP, total nitrogen (TN) and chlorophyll a ( $\mathrm{Chl}$ a) concentrations also varied widely, representing trophic states ranging from oligotrophic to eutrophic. Molar TN:TP ratio spanned three orders of magnitude with a mean of 192. Trophic state indicators (TP, TN and $\mathrm{Chl}$ a) are significantly correlated with $\mathrm{pH}$ which is negatively correlated with water color (Table 2). 
Table 2. Correlation matrix of selected environmental variables from 96 Florida lakes. $p<0.05$ at $\mathrm{r} \geq \pm 0.20$.

\begin{tabular}{|c|c|c|c|c|c|c|c|}
\hline Variable & $\mathrm{pH}$ & Alkalinity & Conductivity & $\mathrm{TP}$ & $\mathrm{TN}$ & Color & Chl a \\
\hline Alkalinity & 0.72 & & & & & & \\
\hline Conductivity & 0.70 & 0.78 & & & & & \\
\hline $\mathrm{TP}$ & 0.21 & 0.15 & 0.03 & & & & \\
\hline $\mathrm{TN}$ & 0.27 & 0.30 & 0.19 & 0.45 & & & \\
\hline Color & -0.38 & -0.24 & -0.31 & 0.10 & 0.04 & & \\
\hline Chl a & 0.48 & 0.33 & 0.17 & 0.37 & 0.46 & -0.13 & \\
\hline TN:TP ratio & -0.20 & -0.13 & -0.18 & -0.16 & -0.02 & 0.12 & -0.13 \\
\hline
\end{tabular}

Table 3. Average (standard deviation) of selected environmental variables grouped by $\delta^{15} \mathrm{~N}_{\mathrm{POM}}$ in the study lakes. Same variable with different letters indicates significant difference (Mann-Whitney test, $p<0.05$ ).

\begin{tabular}{lccc}
\hline & \multicolumn{3}{c}{$\delta^{15} \mathrm{~N}(\%)$} \\
\cline { 2 - 4 } Variables & $\leq 2.0$ & $>2.0 \leq 4.0$ & $>4.0$ \\
\hline$\delta^{15} \mathrm{~N}_{\text {POM }}$ & $0.7(1.1)^{\mathrm{a}}$ & $2.9(0.6)^{\mathrm{b}}$ & $6.2(2.6)^{\mathrm{c}}$ \\
pH & $6.5(1.1)^{\mathrm{a}}$ & $6.8(1.1)^{\mathrm{ab}}$ & $7.1(0.8)^{\mathrm{bc}}$ \\
Alkalinity & $27(37)^{\mathrm{a}}$ & $25(33)^{\mathrm{a}}$ & $24(21)^{\mathrm{a}}$ \\
Conductivity & $120(77)^{\mathrm{a}}$ & $139(82)^{\mathrm{ab}}$ & $169(81)^{\mathrm{bc}}$ \\
Color & $94(104)^{\mathrm{a}}$ & $71(78)^{\mathrm{ab}}$ & $41(35)^{\mathrm{bc}}$ \\
TP & $34(35)^{\mathrm{a}}$ & $46(78)^{\mathrm{a}}$ & $33(43)^{\mathrm{a}}$ \\
$\mathrm{TN}$ & $1.0(0.4)^{\mathrm{a}}$ & $1.1(0.8)^{\mathrm{a}}$ & $1.1(0.9)^{\mathrm{a}}$ \\
Chl a & $13(17)^{\mathrm{a}}$ & $14(20)^{\mathrm{a}}$ & $13(16)^{\mathrm{a}}$ \\
Count & 38 & 28 & 30 \\
\hline
\end{tabular}

$\delta^{15} \mathrm{~N}_{\text {POM }}$ varied from -2.8 to $13.2 \%$ among lakes (Table 1). There are some distinct differences in the environmental variables when lakes were divided into three groups based on $\delta^{15} \mathrm{~N}_{\text {POM }}$ (Table 3). Depleted values $(\leq 2 \% 0)$ were typically found in acidic and highly colored lakes. By contrast, the enriched values $(\geq 4 \%$ ) were associated with lakes characterized by alkaline water and low color content. The environmental variables in lakes with the intermediate $\delta^{15} \mathrm{~N}_{\text {POM }}$ were usually not different from the lakes with depleted and enriched $\delta^{15} \mathrm{~N}_{\text {POM. There }}$ were no differences in the three trophic state indices (TP, TN and Chl a) among the three $\delta^{15} \mathrm{~N}_{\text {POM }}$ groups. Relationships between $\mathrm{pH}$, conductivity, water color and $\delta{ }^{15} \mathrm{~N}_{\text {POM }}$ were significant although all correlation coefficients were low (Figs. 1A to 1C). Likewise, alkalinity, trophic state indices and molar TN:TP ratio was not significantly correlated with $\delta^{15} \mathrm{~N}_{\mathrm{POM}}$ (Figs. 1D to $1 \mathrm{H}$ ).

We examined whether there were differences of $\delta^{15} \mathrm{~N}_{\text {POM }}$ in low and high color lakes within each trophic state class (Fig. 2). With an exception for oligotrophic lakes where $\delta^{15} \mathrm{~N}_{\mathrm{POM}}$ in low-color lakes was significantly higher than that of high-color lakes, $\delta^{15} \mathrm{~N}_{\text {POM }}$ between low color and high color lakes at other trophic classes were not significantly different. We also examined the pattern of $\delta^{15} \mathrm{~N}_{\text {POM }}$ in each trophic state class within each color gradient (Fig. 3). Again, there were large variations in $\delta^{15} \mathrm{~N}_{\text {POM }}$ within each trophic state and color class, but no statistical difference between any trophic and color class. There was no significant relationship between surface area and $\delta^{15} \mathrm{~N}_{\text {POM }}$ (Fig. 4). The poor correlation ( $\mathrm{r}=-0.05$, $p=0.62, n=44)$ is largely due to the elevated $\delta^{15} \mathrm{~N}_{\mathrm{POM}}$ in several small to mid-size lakes and a depleted value from Lake Okeechobee.

\section{Discussion}

\section{Influences of trophic state and nitrogen fixation}

Although phytoplankton $\delta^{15} \mathrm{Nis}$ associated with their growth rate which determinates the magnitude of isotope fractionation (Montoya and McCarthy, 1995; Waser et al., 1998), the present analysis revealed no significant correlation between trophic state indices and $\delta^{15} \mathrm{~N}_{\text {POM }}$ in the 96 study lakes. This finding is consistent with a study of the seasonal cycling of POM isotope composition in Lake Wauberg, Florida (Gu et al., 2006). Lehmann et al. (2004) also found no consistent relationship between $\delta^{15} \mathrm{~N}_{\text {POM }}$, isotopic composition and concentration of nitrate in Lake Lugano. In contrast, a recent review of literature data indicates significantly higher $\delta^{15} \mathrm{~N}_{\text {POM }}$ in eutrophic lakes than in oligotrophic lakes ( $\mathrm{Gu}, 2009)$. However, the author also found large variability of $\delta^{15} \mathrm{~N}_{\text {POM }}$ along the trophic state gradient, suggesting that other environmental variables such as DIN isotope composition and concentration also contributed to the control of $\delta^{15} \mathrm{~N}_{\text {POM }}$ in lakes. Gu et al. (1996) revealed that $\delta^{15} \mathrm{~N}_{\text {POM }}$ of sediment organic matter in Florida lakes increased with nutrient enrichment but then decreased in highly eutrophic lakes. They attributed this pattern of change to the dominance of nitrogen-fixing cyanobacteria in some eutrophic lakes.

The isotopically light POM $(\leq 2.0 \%$ ) from 38 study lakes was likely influenced by planktonic nitrogen fixation (Table 3). We found ${ }^{15} \mathrm{~N}$ depletion in several eutrophic lakes known to have nitrogen-fixing cyanobacterial blooms (Chapman and Schelske, 1997; Havens et al., 1998; Gu et al., 2006). Previous studies have found low $\delta^{15} \mathrm{~N}_{\mathrm{POM}}$ and the presence of nitrogen-fixing cyanobacteria in eutrophic lakes ( $\mathrm{Gu}$ and Alexander, 1993; Lehmann et al., 2004). Patoine et al. (2006) indicated that $\delta^{15} \mathrm{~N}_{\text {POM }}$ was highly correlated with the abundance of cyanobacterial biomass in lakes of the northern Great Plains. Jäntti (2007) showed that decreases in nitrite and nitrate concentrations led to $\mathrm{N}_{2}$-fixing cyanobacteria and low $\delta^{15} \mathrm{~N}_{\text {POM }}$ in the surface water of four Finish lakes. Nitrogen fixation is also common in unproductive lakes and may explain the low $\delta^{15} \mathrm{~N}_{\mathrm{POM}}$ in these lakes. 

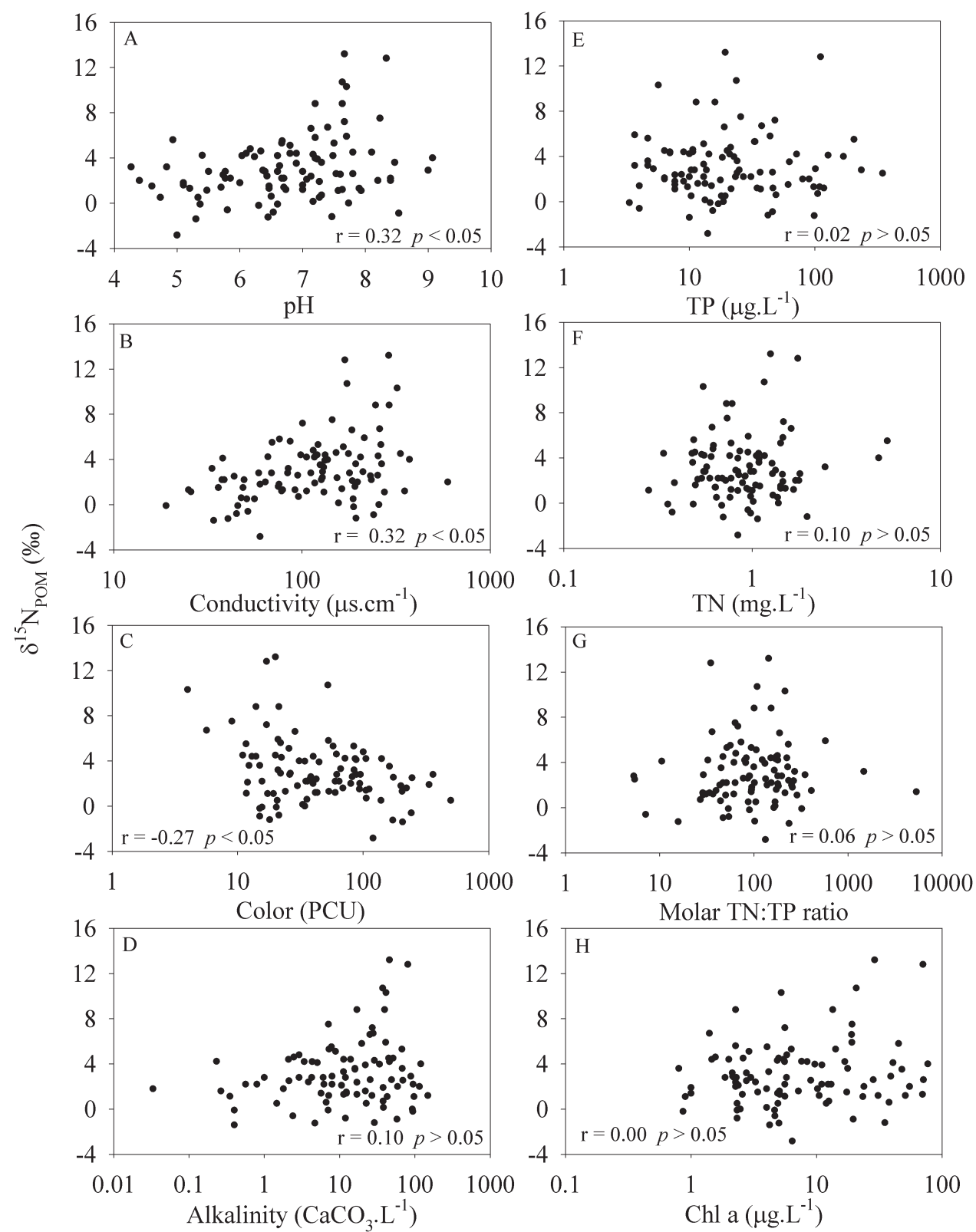

Fig. 1. Relationships between $\mathrm{pH}(\mathrm{A})$, conductivity (B), color (C), alkalinity (D), TP (E), TN (F), molar TN: TP ratio (G), Chl a (H) and $\delta^{15} \mathrm{~N}_{\mathrm{POM}}$ in 96 study lakes. Logarithmical scale is used in $x$-axis except for $\mathrm{pH}$.

For example, ${ }^{15} \mathrm{~N}$ depletion in POM (-0.2 to $2.0 \%$ ) was reported from oligotrophic lakes such as Lake Michigan (Mooy et al., 2001), Lake Malawi (Bootsma et al., 1996) and Lake Mekkojärvi (Jäntti, 2007) where nitrogen-fixing cyanobacteria were noted (MacGregor et al., 2001, Gondwe et al., 2008).

\section{Influences of non-algal materials from autochthonous and allochthonous sources}

In addition of planktonic algae, POM in lakes may also include materials from allochthonous sources, in situ macrophyte and microzooplankton production. Differentiation of organic matter among planktonic algae, terrestrial and aquatic plants using $\delta^{15} \mathrm{~N}$ alone is often difficult because their isotope compositions are sometimes overlapped. The interpretation can be improved with other chemical indicators such as $\mathrm{C}: \mathrm{N}$ ratio, water color and $\delta^{13} \mathrm{C}$. Data for $\mathrm{C}: \mathrm{N}$ ratio are not available for this study. Water color is function of land-derived organic matter that is typically depleted in ${ }^{15} \mathrm{~N}$ (Peterson and Fry, 1987). The negative relationship between water color and $\delta^{15} \mathrm{~N}_{\text {POM }}$ (Table 2) suggests increasing allochthonous contributions to the study lakes. This is consistent with a separate analysis of the same samples by $\mathrm{Gu}$ et al. (submitted) who indicated that the depleted and enriched $\delta^{13} \mathrm{C}$ of POM are indicators for terrestrial and planktonic organic matter in the oligotrophic and eutrophic lakes, respectively. 


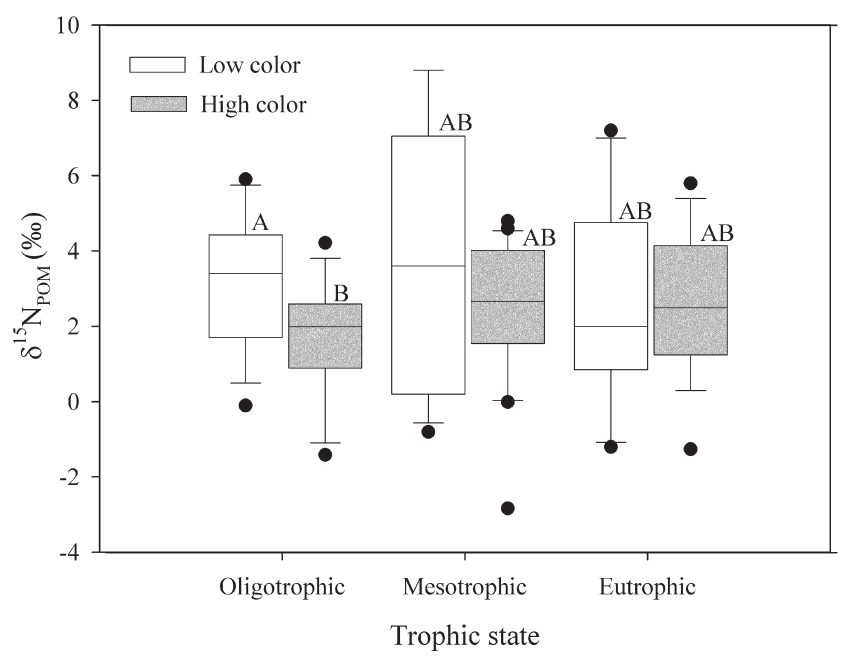

Fig. 2. Box plots of lake trophic state and $\delta^{15} \mathrm{~N}_{\mathrm{POM}}$ at low $(\leq 20$ PCU) and high color ( $>20$ PCU) in the study lakes $(n=96)$. Box boundaries indicate the 25 th and 75 th percentiles; whiskers the 10th and 90th percentiles; the inner horizontal line is the median; circles indicate the 5th and 95th percentiles. Box bars with different letters indicate statistical difference in $\delta^{15} \mathrm{~N}_{\text {POM }}$ (Mann-Whitney test, $p<0.05$ ).

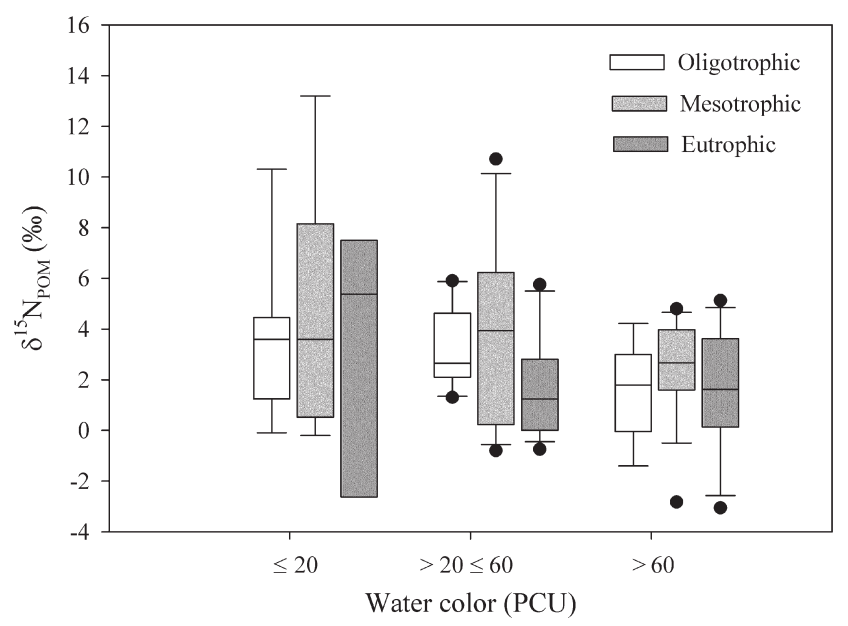

Fig. 3. Box plots of water color and $\delta^{15} \mathrm{~N}_{\mathrm{POM}}$ at different trophic state classes $(n=96)$. Box boundaries indicate the 25 th and 75th percentiles; whiskers the 10th and 90th percentiles; the inner horizontal line is the median; circles indicate the 5th and 95th percentiles. All comparisons are not significantly different (Mann-Whitney test, $p>0.05$ ).

A common contributor to the high $\delta^{15} \mathrm{~N}_{\mathrm{POM}}$ in both oligotrophic and eutrophic lakes is the presence of microzooplankton in water samples. It has been known that consumer $\delta^{15} \mathrm{~N}$ is approximately 3 to $4 \%$ higher than their diets (Post, 2002). In fact, microzooplankton was found in some water samples during POM filtration in this study. In addition, the ${ }^{15} \mathrm{~N}$ enrichment in eutrophic lakes may also be due to the contributions of urban wastes from surface runoff which is an important source of nitrogen to lakes (Carpenter et al., 1998) and is typically enriched

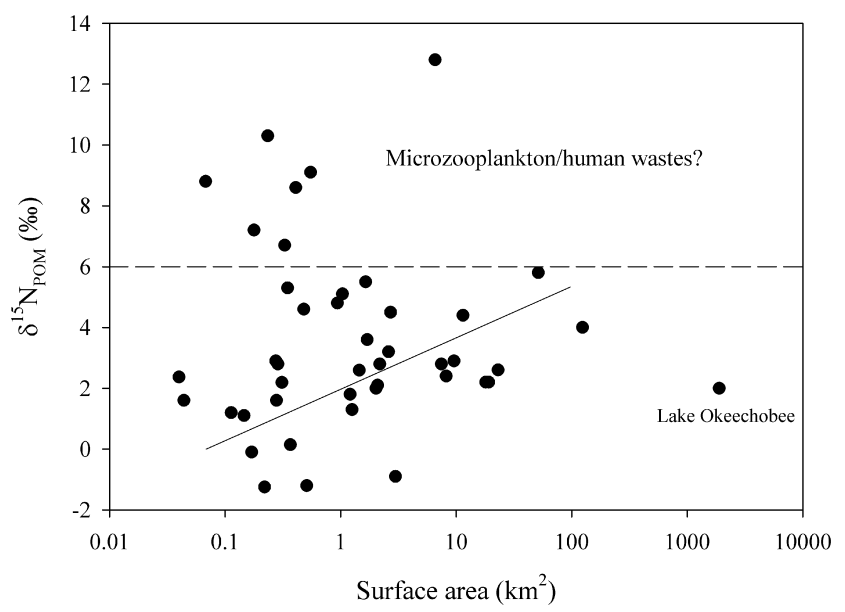

Fig. 4. Scatter plot of surface area and $\delta^{15} \mathrm{~N}_{\text {POM }}$ in the study lakes $(n=44)$. Logarithmical scale is used in $x$-axis. The solid line is the correlation between lake area and $\delta^{15} \mathrm{~N}_{\mathrm{POM}}$ values lying below the horizontal dash line.

with ${ }^{15} \mathrm{~N}$. For example, Lake Taihu in central China is a large urban lake influenced by high human population in the watershed. Anthropogenic disturbances to this lake can be illustrated by high $\delta^{15} \mathrm{~N}$ of DIN and POM (Xie et al., 2007; Zeng et al., 2008). Savage (2005) found high ${ }^{15} \mathrm{~N}(>7 \%)$ in a coastal marine system associated with high sewage discharge. Vander Zanden (2005) indicated that $\delta^{15} \mathrm{~N}$ in primary consumers was influenced by wastewater discharge and may be used as an environmental proxy for anthropogenic disturbances. The high $\delta^{15} \mathrm{~N}_{\mathrm{POM}}$ values above the horizontal line in Figure 4 may be due to the presence of microzooplankton and/or inputs from human wastes. Further study is needed to assess the source materials that are responsible for the high ${ }^{15} \mathrm{~N}$ enrichments in these lakes.

\section{Influences of water color and $\mathrm{pH}$}

In addition to serve as a proxy for the loading of terrestrial humic substances, water color could also serve as an indicator for light availability and phytoplankton growth. The negative correlation between water color and $\delta^{15} \mathrm{~N}_{\text {POM }}$ in the present study also implies a productivitydriven isotope fractionation in POM although a direct relationship between trophic state indices and $\delta^{15} \mathrm{~N}_{\mathrm{POM}}$ cannot be established in our study lakes. There is a large variability of $\delta^{15} \mathrm{~N}_{\mathrm{POM}}$, ranging from -1.2 to $13.2 \%$, in low color lakes $(\leq 20 \mathrm{PCU})$. At low water color, other variables such as nutrients may play more important roles than water color affecting the $\delta^{15} \mathrm{~N}_{\text {POM }}$. With the increases in water color, light becomes a limiting factor for phytoplankton. This explains the decreasing variability of $\delta^{15} \mathrm{~N}_{\text {POM }}$ as water color increased (Fig. 1C). Productivitydriven isotope fractionation is also supported by the positive relationship between $\mathrm{pH}$ and $\delta^{15} \mathrm{~N}_{\mathrm{POM}}$. $\mathrm{pH}$ is significantly correlated with $\mathrm{Chl}$ a (Table 2). Productive 
lakes are typically associated with high $\mathrm{pH}$ and alkaline waters because of strong phytoplankton assimilation of dissolved $\mathrm{CO}_{2}$, leading to elevated $\mathrm{pH}$ in the surface waters.

\section{Influence of nitrogen concentration}

The concentration of nitrogenous nutrients is an important variable controlling $\delta^{15} \mathrm{~N}_{\text {POM }}$ in lakes $(\mathrm{Gu}$, 2009). Isotope fractionation increases as the pool size of the substrate increases (Owens, 1987; Peterson and Fry, 1987). Several previous studies revealed an inverse relationship between DIN concentration and $\delta^{15} \mathrm{~N}_{\text {POM }}$ in individual lakes (Owen et al., 1999; Teranes and Bernasconi, 2000). In contrast, $\mathrm{Gu}$ (2009) found a positive correlation between DIN concentration and $\delta^{15} \mathrm{~N}_{\text {POM }}$ in a review of literature data from global lakes. Other studies, however, failed to find a consistent relationship in individual lakes (Lehmann et al., 2004; Gu et al., 2006). The insignificant relationship between TN and $\delta^{15} \mathrm{~N}_{\mathrm{POM}}$ in the present study is likely partly due to the fact that phytoplankton typically use DIN as their nitrogen source and the surface water TN pool might not be an effective indicator of DIN concentration. On the other hand, given the high $\mathrm{TN}$ concentration and high molar TN:TP ratio in the study lakes (Table 1), nitrogen in general is not a limiting nutrient to phytoplankton growth and the changes in the pool size of nitrogen will not affect $\delta^{15} \mathrm{~N}_{\text {POM }}$ in the lakes.

\section{Influence of lake surface area}

The surface area also can influence $\delta^{15} \mathrm{~N}_{\text {POM }}$ in lakes. Small lakes typically receive higher areal loading of organic matter and nutrients of terrestrial origin with depleted $\delta^{15} \mathrm{~N}$ than large lakes. Lake area has been used to explain differences in $\delta^{13} \mathrm{C}$ of dissolved inorganic carbon (Bade, 2004) and primary consumers (Post, 2002). Gu (2009) also found significantly lower $\delta^{15} \mathrm{~N}_{\text {POM }}$ in small lakes than the mid-size and large lakes. Agricultural runoffs carrying synthetic fertilizer residues depleted in ${ }^{15} \mathrm{~N}$ (Valiela et al., 2000) may be the cause for ${ }^{15} \mathrm{~N}$ depletion in some small lakes. The present study failed to show a significant relationship between lake area and $\delta^{15} \mathrm{~N}_{\text {POM }}$. If the elevated values from several small and mid-size lakes were the result of microzooplankton contamination in samples and the depleted value from Lake Okeechobee was the result of nitrogen fixation, excluding these data would lead to a trend of increasing $\delta^{15} \mathrm{~N}_{\text {POM }}$ along the lake area gradient (Fig. 4), consistent with the recent review of literature data $(\mathrm{Gu}, 2009)$. Lake area is also significantly correlated with $\mathrm{Chl}$ a concentration $(\mathrm{r}=0.38, p<0.05, n=44)$. This may imply that the isotope enrichment along the lake area gradient is also driven by trophic state or primary productivity.

\section{Conclusions}

This analysis with a large data set ( $n=96$ lakes) revealed no significant relationship between trophic state indicators and $\delta^{15} \mathrm{~N}_{\mathrm{POM}}$. Contribution from nitrogen fixation along the trophic state gradient is likely a main reason that a close relationship between trophic state indicators and $\delta^{15} \mathrm{~N}_{\mathrm{POM}}$ cannot be revealed in the present study. This process which acts against ${ }^{15} \mathrm{~N}$ enrichment provides an isotope dilution from atmospheric $\mathrm{N}_{2}$ to the POM pool in both oligotrophic and eutrophic lakes. The importance of nitrogen fixation in lakes is supported by the fact that many lakes have received excessive $\mathrm{P}$ loading and become nitrogen limited.

The ${ }^{15} \mathrm{~N}$ enrichment in eutrophic lakes may reflect high primary productivity by non-nitrogen fixing phytoplankton, the presence of microzooplankton and possibly loadings of ${ }^{15} \mathrm{~N}$-enriched human wastes, whereas ${ }^{15} \mathrm{~N}$ enrichment in some oligotrophic lakes may be the result of microzooplankton presence in the POM samples. Our finding suggests that $\delta^{15} \mathrm{~N}_{\mathrm{POM}}$ is not a robust indicator for lake trophic states, but may serve as a better indicator for the source of nitrogen, especially anthropogenic wastes and biological nitrogen fixation.

Acknowledgements. We thank Florida LAKEWATCH Program for providing water samples and environmental data, and Dave Hodell for providing stable isotope mass spectrometer facility. This study was supported by Carl S. Swisher Endowment, University of Florida Foundation, Inc.

\section{References}

APHA, 1998. Standard methods for the examination of water and wastewater, 20th edition, Washington, DC.

Bade D.L., Carpenter S.R., Cole J.J., Hanson P.C. and Hesslein R.H., 2004. Controls of $\delta^{13}$ C-DIC in lakes: Geochemistry, lake metabolism, and morphometry. Limnol. Oceanogr., 49, $1160-1172$

Bootsma H.A., Hecky R.E., Hesslein R.H. and Turner G.F., 1996. Food partitioning among Lake Malawi nearshore fishes as revealed by stable isotope analyses. Ecology, 77, 1286-1290.

Carpenter S.R., Caraco N.F., Correll D.L., Howarth R.W., Sharpley A.N. and Smith V.H., 1998. Nonpoint pollution of surface waters with phosphorus and nitrogen. Ecol. Appl., 8, 559-568.

Chapman A.D. and Schelske C.L., 1997. Recent appearance of Cylindrospermopsis (Cyanobacteria) in five hypereutrophic Florida lakes. J. Phycol., 33, 191-195.

Delwiche C.C. and Steyn P.L., 1970. Nitrogen isotope fractionation in soils and microbial reactions. Environ. Sci. Tech., 4, 929-935.

Estep M.L.F. and Vigg S., 1985. Stable carbon and nitrogen isotope tracers of trophic dynamics in natural populations and fisheries of the Lahontan Lake system, Nevada. Can. J. Fish. Aquat. Sci., 42, 1712-1719.

Gondwe M.J., Guildford S.J. and Hecky R.E., 2008. Planktonic nitrogen fixation in Lake Malawi/Nyasa. Hydrobiologia, 596, 251-267. 
Gu B., 2009. Variations and controls of nitrogen stable isotopes in particulate organic matter of lakes. Oecologia, 160, 421-431.

$\mathrm{Gu}$ B. and Alexander V., 1993. Estimation of $\mathrm{N}_{2}$ fixation based on differences in the natural abundance of ${ }^{15} \mathrm{~N}$ among freshwater $\mathrm{N}_{2}$-fixing and non- $\mathrm{N}_{2}$-fixing algae. Oecologia, 96 , 43-48.

Gu B., Schell D.M. and Alexander V., 1994. Stable carbon and nitrogen isotopic analysis of the plankton food web in a subarctic lake. Can. J. Fish. Aquat. Sci., 51, 1338-1344.

$\mathrm{Gu}$ B., Schelske C.L. and Brenner M., 1996. Relationship between sediment and plankton isotope ratios $\left(\delta^{13} \mathrm{C}\right.$ and $\delta^{15} \mathrm{~N}$ ) and primary productivity in Florida lakes. Can. $J$. Fish. Aquat. Sci., 53, 875-883.

$\mathrm{Gu}$ B., Chapman A.D. and Schelske C.L., 2006. Factors controlling seasonal variations in stable isotope composition of particulate organic matter in a soft water eutrophic lake. Limnol. Oceanogr., 51, 2837-2848.

Gu B., Schelske C.L. and Waters M., submitted. Patterns and controls of carbon stable isotope composition of particulate organic matter in subtropical lakes. Fundam. Appl. Limol.

Hadas O., Altabet M.A. and Agnihotri R., 2009. Seasonally varying nitrogen isotope biogeochemistry of particulate organic matter in Lake Kinneret, Israel. Limnol. Oceanogr., $54,75-85$.

Havens K.E., Phlips E.J., Cichra M.F. and Li B., 1998. Light availability as a possible regulator of cyanobacteria species composition in a shallow subtropical lake. Freshw. Biol., 39, $547-556$.

Havens K.E., Gu B., Fry B. and Kendall C., 2003. Stable isotope food web analysis of a large subtropical lake: Alternative explanations for ${ }^{15} \mathrm{~N}$ enrichment of pelagic vs. littoral fisheries. The Scientific World Journal, 3, 613-622.

Hoering T.C. and Ford H.T., 1960. The isotope effect in the fixation of nitrogen by Azotobacter. J. Amer. Chem. Soc., 82, 376-378.

Hoyer M.V., Gu B. and Schelske C.L., 1998. Sources of organic carbon in the food webs of two Florida lakes indicated by stable isotopes. In: Jeppesen E.M., Sondergaard M., Sondergaard M. and Christofferson K. (eds.), The structure role of submerged macrophytes in lakes, Springer, BerlinHeidelberg-New York, 326-330.

Jäntti H., 2007. The spatial and temporal variation of nitrogen fixation in aquatic environments, Master Thesis, University of Jyväskylä, 46 p.

Lehmann M.F., Bernasconi S.M., McKenzie J.A., Barbieri A., Simona M. and Veronesi M., 2004. Seasonal variation of the $\delta^{13} \mathrm{C}$ and $\delta^{15} \mathrm{~N}$ of particulate and dissolved carbon and nitrogen in Lake Lugano: constraints on biogeochemical cycling in a eutrophic lake. Limnol. Oceanogr., 49, 415-429.

MacGregor B.J., Van Mooy B., Baker B.J., Mellon M., Moisander P.H., Paerl H.W., Zehr J., Hollander D. and Stahl D., 2001. Microbiological, molecular biological and stable isotopic evidence for nitrogen fixation in the open waters of Lake Michigan. Environ. Microbiol., 3, 205-219.

Montoya J.P. and McCarthy J.J., 1995. Isotopic fractionation during nitrate uptake by phytoplankton grown in continuous culture. J. Plankton Res., 17, 439-464.

Mooy B.V., MacGregor B., Hollander D., Nealson K. and Stahl D., 2001. Evidence for tight coupling between active bacteria and particulate organic carbon during seasonal stratification of Lake Michigan. Limnol. Oceanogr., 46, 1202-1208.

Owen J.S., Mitchell M.J. and Michener R.H., 1999. Stable nitrogen and carbon isotonic composition of seston and sediment in two Adirondack lakes. Can. J. Fish. Aquat. Sci., 56, 2186-2192.

Owens N.J.P., 1987. Natural variations in ${ }^{15} \mathrm{~N}$ in the marine environment. Adv. Mar. Biol., 24, 389-451.

Patoine A., Graham M.D. and Leavitt P.R., 2006. Spatial variation of nitrogen fixation in lakes of the northern Great Plains. Limnol. Oceanogr., 51, 1665-1677.

Peterson B.J. and Fry B., 1987. Stable isotopes in ecosystem studies. Ann. Rev. Ecol. Syst., 18, 293-320.

Post D.M., 2002. Using stable isotopes to estimate trophic position: Models, methods, and assumptions. Ecology, 83, 703-718.

Savage C., 2005. Tracing the influence of sewage nitrogen in a coastal ecosystem using stable nitrogen isotopes. Ambio, 34, 143-148.

Syväranta J., Tiirola M. and Jones R.I., 2008. Seasonality in lake pelagic $\delta^{15} \mathrm{~N}$ values: patterns, possible explanations, and implications for food web baseline. Fundam. Appl. Limnol., 172, 255-262.

Teranes J.L. and Bernasconi S.M., 2000. The record of nitrate utilization and productivity limitation provided by $\delta^{15} \mathrm{~N}$ values in lake organic matter - a study of sediment trap and core sediments from Baldeggersee, Switzerland. Limnol. Oceanogr., 45, 801-813.

Valiela I., Geist M., Mcclelland J. and Tomasky G., 2000. Nitrogen loading from watersheds to estuaries: verification of the Waquoit Bay nitrogen loading model. Biogeochemistry, 49, 277-293.

Vander Zanden M.J., Vadeboncoeur Y., Diebel M.W. and Jeppensen E., 2005. Primary consumer stable nitrogen isotopes as indicators of nutrient source. Environ. Sci. Technol., 39, 7509-7515.

Waser N.A.D., Harrison P.J., Nielsen B., Calvert S.E. and Turpin D.H., 1998. Nitrogen isotope fractionation during the uptake and assimilation of nitrate, nitrite, ammonium, and urea by a marine diatom. Limnol. Oceanogr., 43, 215-224.

Xie Y.X., Xiong Z.Q., Xing G.X., Sun G.Q. and Zhu Z.L., 2007. Assessment of nitrogen pollutant sources in surface waters of Taihu Lake region. Pedosphere, 17, 200-208.

Zeng Q.F., Kong F.X., Zhang E.L., Tan X. and Wu X.D., 2008. Seasonality of stable carbon and nitrogen isotopes within the pelagic food web of Taihu Lake. Ann. Limnol. - Int. J. Lim., $44,55-60$. 